\title{
Therapeutic Potency of the Polar and Non-Polar Extracts of Andrographis Paniculata Leaf Against some Pathogenic Bacterial Isolates
}

\author{
Ayanwale 0 Abraham ${ }^{1 *}$, Adabara U Nasiru ${ }^{1}$, Adeniyi K Abdulazeez ${ }^{2}$, Oyewole 0 Seun $^{3}$ and David W Ogonna ${ }^{4}$ \\ ${ }^{1}$ Department of Microbiology, Federal University of Technology, Nigeria \\ ${ }^{2}$ Department of Animal Biology, Federal University of Technology, Nigeria \\ ${ }^{3}$ Department of Microbiology, Obafemi Awolowo University, Nigeria \\ ${ }^{4}$ Department of Biochemistry and molecular biology, Obafemi Awolowo University, Nigeria
}

*Corresponding author: Ayanwale O Abraham, Department of Microbiology, Federal University of Technology, Minna, Nigeria.
Received Date: November 04, 2019

Published Date: November 18, 2019

\begin{abstract}
The increasing resistance among virulent pathogens and the toxicity of synthetic antibiotic has led to the quest for bioactive natural products which are safe, potent, and affordable for therapeutic purpose. This study evaluated the antibacterial activities of polar and non-polar extracts from Andrographis paniculata leaf $(80,120,160$ and $200 \mathrm{mg} / \mathrm{mL})$ against Staphylococcus aureus, Streptococcus pyogenes, Escherichia coli, and Salmonella typhi. Phytochemicals screening were conducted using standard procedures while the antibacterial activity was evaluated using agar well diffusion technique. Results revealed the presence of alkaloid, phenol, flavonoids, steroids, terpenoids, and saponins in methanol extract while the N-Hexane extract contains alkaloids, phenols, and steroids. Cardiac glycosides and tannins were absent in both extracts. Both extracts exhibited increase growth inhibition of S. aureus, E. coli and S. typhi with increase extract concentration. Methanol extract exhibited higher activities $(3.00 \pm 0.01$ and $25.00 \pm 0.01 \mathrm{~mm})$ than the hexane extract $(3.00 \pm 0.01$ and $20.00 \pm 0.01 \mathrm{~mm})$. The MIC of methanol extract were $1.60,0.32 \mathrm{and} 0.32 \mathrm{mg} / \mathrm{mL}$ while hexane extract recorded MIC of 8.0, 2.60 and $2.60 \mathrm{mg} / \mathrm{mL}$ against $S$. aureus, E coli and S. typhi respectively. Thus, Andrographis paniculata leaf might be a useful tool in the future for pharmaceuticals antibiotics.
\end{abstract}

Keywords: Andrographis paniculate; Antibacterial activities; Phytochemicals; Polar; Non-polar solvents

\section{Introduction}

Infectious diseases remain the primary cause of mortality and morbidity in developing countries, resulting in substantial economic loss and threaten the attainment of the Sustainable Development Goals (SDGs), which highlighted healthcare as one of the topmost challenges for 2030 [1,2]. The re-current emergence of drug-resistant pathogens and the toxicity of conventional synthetic antibiotics [3], further necessitate the need for the discovery of less toxic and yet potent natural alternatives, hence the continuous screening of plants and other natural products for therapeutic efficacy $[4,5]$. Medicinal plants have grown enormously from the use of herbal products as natural cosmetics and as self-medication by the general public scientific for their beneficial effects [6].
Medicinal plants still play important role in human and animal health care and about $60 \%$ of the world's population (and $80 \%$ of Africa's population) depend on herbal medicine for their primary health care [7]. Many of these plants have been screened for their phytochemical constituents and antimicrobial properties with the view to authenticate their folkloric uses and safety [8]. Plants have various phytochemical compounds and metabolites occurring in the stem, roots, bark, leaves and have been implicated to have therapeutic efficacy against man's pathogens such as fungi and bacteria [9]. Andrographis paniculata, commonly known as "king of bitters," is a shrub found in many countries of Africa, Asia, and America. It has been well documented for treating diabetes, high 
blood pressure, skin diseases, influenza, dysentery, bronchitis, leprosy, ulcer, flatulence [10]. Extract from the plant has been reported to contain xanthones, flavonoids, diterpenes, noriridoides, which have demonstrated antiprotozoal, anti-inflammatory, antioxidants, immunostimulants, anti-diabetics, anti-angiogenic, cytotoxicity, sex hormones functions [10,11]. Evidence from published literature recently concentrated on the aqueous and methanol extracts of Andrographis paniculata. The lack of current information informed this study to elucidate the effects of polar and non-polar bioactive extracts from A. paniculata against some clinical bacteria isolates.

\section{Materials and Methods}

\section{Collection and identification of the plant materials}

Leaves of Andrographis paniculata were collected from the Botanical garden of Federal University of Technology, Minna, Latitude N9039'17.32608" and Longitude E6031'39.07164." The collected sample was identified at the Department of Plant Biology of the Federal University of Technology, Minna.

\section{Bacteria strains}

The bacteria pathogens used in the antimicrobial activity screening of the methanol and n-hexane extracts of Andrographis paniculata were E. coli, Staphylococcus aureus, Streptococcus pyogenes and Salmonella typhi. The test organisms were obtained from Niger State General Hospital, Minna.

\section{Processing and extraction of plant material}

Freshly collected leaves of the A. paniculata were thoroughly rinsed with distilled water and dried at room temperature for one week; the dried leaves were then processed into powder form using a clean electric blender. A $40 \mathrm{~g}$ of the powder was extracted using the Soxhlet apparatus with solvents methanol $(160 \mathrm{ml})$ and $\mathrm{N}$-hexane $(150 \mathrm{ml})$. The concentration of the extracts was done using the reflux method, as described by [12]. The crude extracts were weighed and preserved in a sterile air-tight universal bottle and stored at $4^{\circ} \mathrm{C}[13]$.

\section{Phytochemical screening}

The crude methanol and hexane extracts of were analyzed for qualitative phytochemical composition including; Alkaloid, phenol, flavonoids, steroids, terpenoids, saponins, cardiac glycosides and tannins using standard procedures Poongothai et al. Hosamani et al. [14].

\section{Culture and standardization of the bacteria strain}

The clinical isolates of the test organism were plated out on nutrient agar by streaking method, a loopful of the test microorganisms were then transferred into $5 \mathrm{ml}$ of nutrient broth; this was later incubated for 24 hours at $37^{\circ} \mathrm{C}$. After incubation, 0.2 $\mathrm{ml}$ of the culture was transferred into $20 \mathrm{ml}$ of nutrient brought and incubated for 3-5 hours to standardize the culture to $106 \mathrm{cfu} / \mathrm{ml}$ Babayi et al.

\section{Antibacterial assay}

The following bacteria: S. pyogenes, Salmonella typhi, Staphylococcus aureus and Escherichia coli were the species used for the experiments. Organisms were isolated by standard methods, maintained on agar plates and refrigerated until further use. The antibacterial activity of the methanol and hexane extract of Andrographis paniculata at various concentrations $(80,120$, 160 and $200 \mathrm{mg} / \mathrm{ml}$ ) was carried out using agar-well diffusion method according to the method of [15] as described by [16] For comparison, Ampicillin and tween 80 oil were used as positive and negative control respectively. Zones of inhibition obtained were measured with meter rule in millimeter, $5 \mathrm{~mm}$ which is the diameter of the used cork borer was subtracted from each measured inhibition zones, the final result is taken as the zones of inhibition [17]. A broth micro-dilution method [18] was used to determine the minimum inhibitory concentration (MIC) of the extracts.

\section{Data analysis}

Data generated were analyzed using statistical package for social science (SPSS) version 21. Differences between groups were compared by analysis of variance (ANOVA) followed by Duncan's Multiple Range Test. The significance level was considered $\mathrm{P}<0.05$.

\section{Result}

\section{Phytochemical composition andrographis paniculata}

The phytochemical constituents of the methanol and N-Hexane extract of $A$. panicaulata is presented in Table 1 Methanol extract of Andrographis paniculata was found to contain alkaloid, phenol, flavonoids, steroids, terpenoids, and saponins while the N-Hexane extract contains alkaloids, phenols, and steroids. Cardiac glycosides and tannins were absent in both extracts (Table 1).

Table 1: Phytochemical composition of the methanol and n-hexane extract of Andrographis panculata.

\begin{tabular}{|c|c|c|}
\hline Phytochemical & Methanol & N-hexane \\
\hline Alkaloids & + & + \\
\hline Cardiac Glycosides & - & - \\
\hline Phenols & + & + \\
\hline Tannins & - & - \\
\hline Flavonoids & + & - \\
\hline Steroids & + & + \\
\hline Terpenoids & + & - \\
\hline Saponins & + & - \\
\hline
\end{tabular}

Keys: + = Present, - = Absent.

\section{Antibacterial activity}

The zone of inhibition of m ethanol and N-hexane extracts of $A$. paniculata on the tested organism is shown in Table 2,3 respectively. Methanol extract of Andrographis paniculate inhibited the growth of S. aureus, E. coli and S. typhi with inhibition zone range of $3.00 \pm 0.01$ and $25.00 \pm 0.01 \mathrm{~mm}$. However, the extract was completely in active against $S$. pyogenes. The inhibition zone of the extract against the organism increase with increase extract concentration from 80 to 
$200 \mathrm{mg} / \mathrm{mL}$. the extract was more active against $E$. coli $(6.00 \pm 0.01$ $\mathrm{mm}$ to $25.00 \pm 0.01 \mathrm{~mm})$, followed by $S$. typhi $(10.00 \pm 0.00 \mathrm{~mm}$ and $22.00 \pm 0.03 \mathrm{~mm}$ ) while the least activity was recorded against $S$. aureus $(3.00 \pm 0.01 \mathrm{~mm}$ and $18.00 \pm 0.02 \mathrm{~mm})$ Table 2. Similarly, hexane extract was in active against $S$. pyogenes but the inhibition zones $(3.00 \pm 0.01$ and $20.00 \pm 0.01 \mathrm{~mm})$ caused by the extract against $S$. aureus, E. coli and $S$. typhi increase with increase extract concentration from 80 to $200 \mathrm{mg} / \mathrm{mL}$. The extract was more active against $E$. coli and less active against $S$. aureus (Table 2,3).

Table 2: Zone of inhibition ( $\mathrm{mm}$ ) of the Methanol extract of Andrographis paniculata against the organism.

\begin{tabular}{|c|c|c|c|c|c|c|}
\hline \multirow{2}{*}{ Isolates } & \multicolumn{4}{|c|}{ Concentrations of Extract(mg/ml) } & \multicolumn{2}{|c|}{ Control } \\
\hline & 80 & 120 & 160 & 200 & $+_{\mathrm{ve}}$ & $--_{\text {ve }}$ \\
\hline S. aureus & $3.00 \pm 0.01^{\mathrm{b}}$ & $9.80 \pm 0.01^{\mathrm{b}}$ & $12.40 \pm 0.01^{\mathrm{b}}$ & $18.00 \pm 0.02^{\mathrm{b}}$ & $25.00 \pm 0.01^{\mathrm{b}}$ & $0.00 \pm 0.00^{\mathrm{a}}$ \\
\hline E. coli & $6.00 \pm 0.01^{\mathrm{c}}$ & $10.20 \pm 0.02^{c}$ & $11.50 \pm 0.01^{\mathrm{b}}$ & $25.00 \pm 0.01^{\mathrm{d}}$ & $28.00 \pm 0.02^{\mathrm{d}}$ & $0.00 \pm 0.00^{\mathrm{a}}$ \\
\hline S. typhi & $10.00 \pm 0.00^{c}$ & $12.0 \pm 0.01^{\mathrm{d}}$ & $15.00 \pm 0.03^{c}$ & $22.00 \pm 0.03^{c}$ & $23.00 \pm 0.01^{\mathrm{a}}$ & $0.00 \pm 0.00^{\mathrm{a}}$ \\
\hline S. pyogenes & $0.00 \pm 0.00^{\mathrm{a}}$ & $0.00 \pm 0.00^{\mathrm{a}}$ & $0.00 \pm 0.00^{\mathrm{a}}$ & $0.00 \pm 0.00^{\mathrm{a}}$ & $26.00 \pm 0.02^{\mathrm{c}}$ & $0.00 \pm 0.00^{\mathrm{a}}$ \\
\hline
\end{tabular}

Values are presented in mean \pm standard error of two determinations. Values followed with the same superscripts alphabets on the same column are not significantly different at $p>0.05$

Table 3: Zone of inhibition ( $\mathrm{mm}$ ) of the $\mathrm{n}$-Hexane extract of Andrographis paniculata against the organism.

\begin{tabular}{|c|c|c|c|c|c|c|}
\hline \multirow{2}{*}{ Isolates } & \multicolumn{4}{|c|}{ Concentrations of Extract(mg/ml) } & \multicolumn{3}{c|}{ Control } \\
\cline { 2 - 7 } & $\mathbf{8 0}$ & $\mathbf{1 2 0}$ & $\mathbf{1 6 0}$ & $\mathbf{2 0 0}$ & $+_{\text {ve }}$ & $-_{\text {ve }}$ \\
\hline S.aureus & $7.00 \pm 0.02^{\mathrm{d}}$ & $7.50 \pm 0.01^{\mathrm{c}}$ & $11.0 \pm 0.30^{\mathrm{c}}$ & $15.0 \pm 0.02^{\mathrm{c}}$ & $25.00 \pm 0.01^{\mathrm{b}}$ & $0.00 \pm 0.00^{\mathrm{a}}$ \\
\hline Ecoli & $3.00 \pm 0.01^{\mathrm{b}}$ & $5.00 \pm 0.02^{\mathrm{b}}$ & $8.00 \pm 0.01 \mathrm{~b}$ & $12.00 \pm 0.03^{\mathrm{b}}$ & $28.00 \pm 0.02^{\mathrm{d}}$ & $0.00 \pm 0.00^{\mathrm{a}}$ \\
\hline S. typhi & $6.00 \pm 0.01^{\mathrm{c}}$ & $9.00 \pm 0.01^{\mathrm{d}}$ & $11.00 \pm 0.02^{\mathrm{c}}$ & $20.00 \pm 0.01^{\mathrm{c}}$ & $23.00 \pm 0.03^{\mathrm{a}}$ & $0.00 \pm 0.00^{\mathrm{a}}$ \\
\hline S.pyogenes & $0.00 \pm 0.0^{\mathrm{a}}$ & $0.00 \pm 0.00^{\mathrm{a}}$ & $0.00 \pm 0.00^{\mathrm{a}}$ & $0.00 \pm 0.00^{\mathrm{a}}$ & $26.00 \pm 0.01^{\mathrm{c}}$ & $0.00 \pm 0.0^{\mathrm{a}}$ \\
\hline
\end{tabular}

Values are presented in mean \pm standard error of two determinations. Values followed with the same superscripts alphabets on the same column are not significantly different at $p>0.05$

Table 4: Minimum Inhibitory Concentration of Methanol and hexane Extract of Andrographis paniculate.

\begin{tabular}{|c|c|c|}
\hline Isolates & Methanol $(\mathrm{mg} / \mathrm{ml})$ & Hexane $(\mathrm{mg} / \mathrm{ml})$ \\
\hline S. aureus & 1.6 & 8 \\
\hline Ecoli & 0.32 & 2.6 \\
\hline S. typhi & 0.32 & 2.6 \\
\hline
\end{tabular}

\section{Minimum Inhibitory concentration (MIC)}

The minimum inhibitory concentration of methanol and hexane extracts of Andrographis paniculate is shown in Table 4. The MIC of methanol extract of Andrographis paniculate were 1.60, 0.32 and $0.32 \mathrm{mg} / \mathrm{mL}$ against $S$. aureus, E coli and $S$. typhi respectively. Hexane extract however, recorded MIC of 8.0, 2.60 and $2.60 \mathrm{mg} / \mathrm{mL}$ against $S$. aureus, E coli and $S$. typhi respectively (Table 4 ).

\section{Discussion}

Medicinal plants have gained high attention as alternative to conventional therapy. Studies on the medicinal potentials of plants as reported by $[19,20]$ revealed that extraction solvents such as n-hexane, ethyl acetate, methanol and water have different affinities for phytochemical compounds. In the present study, methanol extract of Andrographis paniculata was found to contain alkaloid, phenol, flavonoids, steroids, terpenoids, and saponins while the $\mathrm{N}$-Hexane extract contains alkaloids, phenols, and steroids. In agreement with the present study [21], demonstrated the presence of Alkaloids, Phenols, and Terpenoids and Saponin in the methanol extracts of A. paniculata. While the study of [22] revealed the presence of Alkaloids and Terpenoids in the $\mathrm{N}$-Hexane extract of $A$. paniculata. The presence of these bio-active metabolites such as Alkaloids, phenols, and steroids is an indication that the plant will possess therapeutic activities [5] Alkaloids, phenols and flavonoids, for instance, have been previously identified as antimicrobial compounds [23,24]. They have been extensively used in disinfection and remained the standard with which other bactericides are compared [25]. Also, alkaloids and flavonoids are used as basic medicinal agents for their bactericidal, analgesic and antispasmodic effects [26,24]. These phytochemicals may be acting singly or synergistically with each other to bring about a cidal or static effect on the microorganisms [27]. The discrepancy in the phytochemical compositions of the two extract and also the absence of Cardiac glycosides and tannins in both extracts could be attributed to the differences in the polarity of the solvent used. Previous study has reported that not all phytochemicals are present in all plants and also that phytochemical composition of medicinal plants can be rationalized in terms of the organ of the plant used as well as the solvent used in the extraction process [28].

In the present study, the plant extract showed dose-dependent antibacterial activities against E. coli, S. typhi, and S. aureus. These could be as a result of an increase in extract concentration which gives a resultant increase in bioactive compound constituent and efficacy. According to [29], dose-dependent potency is common to bioactive compounds from plants. The methanol extract showed higher antibacterial potency than the N-Hexane extract. This could be attributed to the higher qualitative phytochemical composition of the methanol extract than the hexane extract. The observation may be correlated to the nature of bioactive compounds whose activity can be increased in the presence of more polar solvents. According to [30], polar solvents have a higher ability to extract 
more bioactive compounds than non-polar solvents. The tested microorganisms were inhibited at a very low concentration of the Methanol and N-hexane extract of Andrographis paniculata. E. coli and Salmonella were the most susceptible to having a zone of inhibition of $25 \mathrm{~mm}$ and $20 \mathrm{~mm}$, respectively. The MIC values $0.32 \mathrm{mg} / \mathrm{ml}$, obtained for the tested pathogens for the methanol extract in both the E. coli and $S$. typhi, is an indication of a strong therapeutic potency at low concentrations. This result is similar to that obtained by [31], who discovered that the methanol extract of A. paniculata has high antibacterial activity against Salmonella and E. coli than on Gram-positive bacteria. However [32,33], showed contradicting results to the present study [32]. reported that the methanol extracts of $A$. paniculata have stronger antibacterial activity against gram positive bacteria than on Gram Negative bacteria. From his study, Staphylococcus aureus has an inhibitory zone of $(21 \mathrm{~mm})$ at $25 \mu \mathrm{l}$ of methanol extract of the plant, at this same concentration, E. coli was not inhibited. [33] also reported that the methanol and the hexane extract of $A$. paniculata have no inhibitory effect on $E$. coli even at a high concentration of $200 \mu \mathrm{g} /$ $\mathrm{ml}$. The variation in results may be due to the differences in the nature of the phytochemical constituents available in the extracts, which are primarily determined by the method of extractions [14]. Also, difference in geographical location of the plant material could also cause variation in the quality as well as the quantity of bioactive metabolite in the plant, thus contributing to the variation in biological activitie [34].

\section{Conclusion}

The current study revealed the presence of bioactive metabolites in both methanol and N-Hexane extracts of A. paniculata. The methanol and the N-Hexane extracts from the leaf of $A$. paniculata showed significant antibacterial activity against Salmonella typhi, E. coli, S. aureus. Methanol extract however, demonstrated higher activities than the Hexane extract. Thus, it might be a useful tool in the future for pharmaceuticals antibiotics. It will be of utmost benefit to study the antiviral potency of this leaf against debilitating viral infections such as Rabies, Dengue, Hepatitis, etc.

\section{Acknowledgement}

None

\section{Conflict of interest}

The authors declare that no conflict of interest.

\section{References}

1. Asokan GV, Kasimanickam RK (2013) Emerging Infectious Diseases, Antimicrobial Resistance and Millennium Development Goals: Resolving the Challenges through One Health. Central Asian journal of global health 2(2): 76

2. Holmes KK, Bertozzi S, Bloom BR, Jha P, Gelband H, et al. (2017) Major Infectious Diseases: Key Messages from Disease Control Priorities, Third Edition. Holmes KK, Bertozzi S, Bloom BR (Eds) Major Infectious Diseases. 3rd edition. Washington (DC): The International Bank for Reconstruction and Development / The World Bank, Chapter 1.

3. Nurgali K, Jagoe RT, Abalo R (2018) Editorial: Adverse Effects of Cancer Chemotherapy: Anything New to Improve Tolerance and Reduce Sequelae? Frontiers in pharmacology 9: 245
4. Cheesman MJ, Ilanko A, Blonk B, Cock IE (2017) Developing New Antimicrobial Therapies: Are Synergistic Combinations of Plant Extracts/Compounds with Conventional Antibiotics the Solution? Pharmacognosy reviews 11(22): 57-72.

5. Ibrahim AM, Lawal B, Abubakar AN, Tsado NA, Kontagora GN, et al. (2017) Antimicrobial and Free Radical Scavenging Potentials of N-Hexane and Ethyl Acetate Fractions of Phyllanthus Fraternus. Nigerian Journal of Basic and Applied Science 25(2): 06-11.

6. Sharma M, Joshi S (2011) Comparison of anti-oxidant of Andrographis paniculata and Tinospora cordifolia leaves. J Curr Chem Pharm Sc 1(1): $1-8$

7. WHO (2016) General Guidelines for Methodologies on Research \& Evaluation of Traditional Medicine? World Health Organization 2000, Geneva.

8. STahir Ali, A Ayub, SN Ali, S Begum, BS Siddiqui, et al. (2017) Antibacterial activity of methanolic extracts from some selected medicinal plants. Fuuast Journal of Biological sciences 7(1): 123-125

9. Ngulde SI, Sandabe UK, Tijjani MB, Barkindo AA, Hussaini IM (2013) Phytochemical constituents, antimicrobial screening \& acute toxicity studies of the ethanol extract of Carissa edulis Vahl. root bark in rats \& mice. American Journal of Research Communication 11(9): 91-110.

10. Akhbar S (2011) Andrographis paniculata: A review of pharmacological activities and clinical effects. Alternative Medicine Effect 16(1): 66-77.

11. Aniel KO, Mutyala NL, Rao KGR (2010) In vitro antibacterial activity in the extracts of Andrographis paniculata Burm. F. International Journal of Pharmaceutical Research 2(2): 1383-1385.

12. Zhang QW, Lin L G, Ye WC (2018) Techniques for extraction and isolation of natural products: a comprehensive review. Chinese medicine 13: 20.

13. Gurupriya S, Cathrine L (2016) Antimicrobial activity of Andrographis paniculata stem extracts. International Journal of Scientific \& Engineering Research 7(8): 2229-5518.

14. Ramos JU, David SE, Waing GD (2016) Phytochemical screening and antibacterial testing of different varieties of Morus spp. (Mulberry). Journal of Biological Engineering Research and Review 3(1): 44-48.

15. CLSI (2012) Method for antimicrobial susceptibility testing of Anaerobic Bacteria; Approved standard, eight edition. CLSI document M11-A8. Wayne, PA. Clinical and Laboratory Standard Institute.

16. Tsado NA, Lawal B, Ossa PC, Jagaba A, Kontagora GN, et al. (2016a) Antioxidants and Antimicrobial Activities of Methanol Extract of Newbouldia laevis and Crateva adansonii. Journal of Pharmacy and Allied Health Sciences 6(1-2): 14-19.

17. Morsi N (2000) Antimicrobial effect of crude extracts of Andrographis paniculata on multiple resistants bacteria. Journal of Microbiology 49: 63-74.

18. Eloff JNA (1998) Sensitive and quick microplate method to determine the minimal inhibitory concentration of plant extracts for bacteria. Planta Medica 64(8): 711-713.

19. Ibrahim AM, Lawal B, Tsado NA, Yusuf AA, Jimoh AM (2015) Phytochemical Screening and GC-MS Determination of Bioactive Constituents from Methanol Leaf Extract of Senna occidentalis. Journal of Coastal Life Medicine 3(12): 992-995.

20. Tsado NA, Lawal B, Kontagora GN, Muhammad BM, Yahaya MA, et al. (2016b) Antioxidants and Antimicrobial- Activities of Methanol Leaf Extract of Senna occidentalis. Journal of Advances in Medical and Pharmaceutical Sciences 8(2): 1-7.

21. Das P, SrivastavAK (2014) Phytochemical Extraction and Characterization of the Leaves of Andrographis Paniculata for Its Anti-Bacterial, AntiOxidant, Anti-Pyretic and Anti Diabetic Activity. International Journal of Innovative Research in Science, Engineering and Technology 3(8): $15176-15184$.

22. Chandra P, Sudhakran R, Krishna A, Arya B, Priya S, et al. (2017) Analysis of Phytochemical Constituents, Anthelmintic and Insecticidal Properties of Leaf Extracts of Andrographis paniculata. The Pharmaceutical and Chemical Journal 4(5): 98-106. 
23. Othman L, Sleiman A, Abdel Massih RM (2019) Antimicrobial Activity of Polyphenols and Alkaloids in Middle Eastern Plants. Frontiers in microbiology 10: 911.

24. Umar SI, Lawal B, Mohammed BA, Obiekezie CI, Adewuyi AH, et al. (2019) Antioxidant and Antimicrobial Activities of Naturally Occurring Flavonoids from M. heterophylla and the Safety Evaluation in Wistar Rats. Iran J Toxicol 13(4): 39-44.

25. Ogbunugafor HA, Ugochukwu CG, Kyrian Ogbonna AE (2017) The role of spices in nutrition \& health: a review of three popular spices used in Southern Nigeria. Food Quality \& Safety 1(3): 171-185.

26. Jigam AA, Mahmood F, Lawal B (2017) Protective effects of crude and alkaloidal extracts of Tamarindus indica against acute inflammation andnociception in rats. Journal of Acute Disease 6(2): 78-81.

27. Yusuf AA, Lawal B, Yusuf MA, Omonije YO, Adejoke AA, et al. (2018) Free Radical Scavenging, Antimicrobial Activities and Effect of Sub-Acute Exposure to Nigerian Xylopia Aethiopica Seed Extract on Liver and Kidney Functional Indices of Albino Rat. Iranian journal of toxicology 12(3): 51-58.

28. Lawal B, Ossai PC, Shittu OK, Abubakar AN (2014) Evaluation of Phytochemicals, Proximate, Minerals and Anti-Nutritional Compositions of Yam Peel, Maize Chaff and Bean Coat. International Journal of Applied Biological Research 6(2): 21-37.
29. Zhao Y, Wu Y, Wang M (2015) Bioactive Substances of Plant Origin. Cheung P, Mehta B (Eds.), Handbook of Food Chemistry, Heidelberg, Germany.

30. Dhawan D, Gupta J (2016) Comparison of different solvents for phytochemical extraction potential from Datura metel plant leaves. International Journal of Biological Chemistry 11(1): 17-22.

31. Shalini VB, Narayanan JS (2015) Antibacterial activity of Andrographis paniculata Nees against selective human pathogens. African Journal of Microbiology Research 9(16): 1122-1127.

32. Nanthini R, Athinarayanan G, Ranjitsingh Aja, Mariselvam R, Chairman K, et al. (2013) antimicrobial activity of leaf extracts of the medicinal plants andrographis paniculata and Melia Azadirach L. International Journal of Current Research 5(11): 3563-3566.

33. Deepak S, Pawar A, Shinde P (2014) Study of antioxidant and antimicrobial activities of Andrographis paniculate. Pelagia Research Library Asian Journal of Plant Science and Research 4(2): 31-41.

34. Lawal B, Shittu OK, Oibiokpa FI, Berinyuy EB, Muhammed H (2016) African natural products with potential antioxidants and hepatoprotectives properties: a review. Clinical Phytoscience 2(23): $1-66$. 